\title{
Correction to: Introduction: Turkey's National Television in Transnational Context
}

\author{
Yesim Kaptan and Ece Algan
}

\section{Correction to:}

Chapter 1 in: Y. Kaptan, E. Algan (eds.), Television in Turkey, https://doi.org/10.1007/978-3-030-46051-8_1

The original chapter title of this book was revised owning to a mistake in Chapter 1, it has been corrected to "Introduction: Turkey's National Television in Transnational Context.

The updated version of this chapter can be found at https://doi.org/10.1007/978-3-030-46051-8_1

(C) The Author(s) 2021 